\title{
Por entre lutas, entusiasmo e prazer: entrevista com Clair Castilhos
}

Between Fights, Enthusiasm and Pleasure: Interview with Clair Castilhos

\author{
Carmen Susana Tornquist ${ }^{1}$ (D) 0000-0002-7560-8649 \\ Silvana Maria Pereira ${ }^{2}$ (i) 0000-0002-1925-3273 \\ Binah Ire Vieira Marcellino2 (iD 0000-0002-3326-2432 \\ Universidade do Estado de Santa Catarina, Departamento de Geografia, \\ Florianópolis, Santa Catarina, Brasil. 88040-560 \\ 2Universidade Federal de Santa Catarina, Florianópolis, Santa Catarina, Brasil.
}

$88040-900$

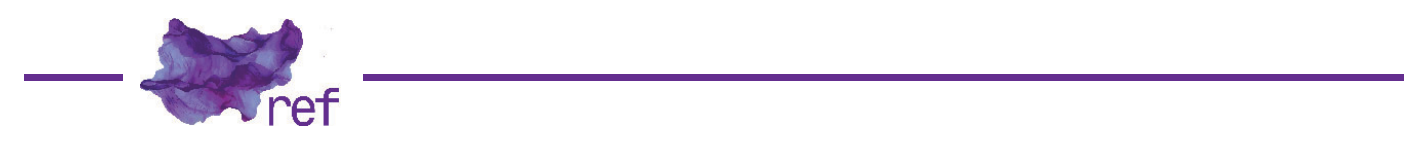

Bastante conhecida no campo da saúde e da saúde das mulheres, na América Latina e no Brasil, Clair Castilhos expressa bem o feminismo surgido no Brasil no final da ditadura empresarial militar de 1964. A entrevista que segue foi realizada em julho de 2017, em Florianópolis, na casa de Clair, no Córrego Grande. As baixas temperaturas daquela tarde foram mitigadas pelo entusiasmo característico de nossa entrevistada, primeira vereadora mulher - e feminista - que a cidade de Florianópolis conheceu.

Da longa conversa que estabelecemos, foram retirados, aqui, alguns trechos focados mais especificamente nos processos partidários locais, cuja compreensão seria dificultada para a maioria das leitoras. Incorporamos, todavia, como forma de registro e de memória, os documentos históricos que tratam da comemoração do 8 de Março, realizada na Câmara Municipal de Florianópolis, em 1982. Neste evento, Clair apresentou, de forma contundente, à Câmara de Vereadores, a "questão das mulheres", em conjunto com grupos de reflexão feministas que se organizavam na cidade, nesse momento, junto com outros movimentos sociais que se expressavam localmente, assim como em todo o país, nos primeiros anos da chamada transição democrática.

Destacamos na entrevista desta gaúcha radicada em Santa Catarina desde os anos de 1980 suas memórias pontuadas por um cosmopolitismo típico das regiões fronteiriças, como a do Rio Grande do Sul com o Uruguai, onde nasceu e a partir do qual vão se descortinando as peculiaridades da vida política entre Sant'Ana do Livramento e Rivera, cidades onde passou sua infância e adolescência. De lá partiu, nos idos dos tempos em que o patriotismo era um "valor", forma como caracterizou sua formação escolar no final do período getulista.

De fala contundente e firme, sem deixar de ser suave, Clair fala de sua trajetória lembrando os contadores de causos, comuns nesta região, com elementos cômicos e ironias, compassadas pela franqueza e simplicidade. É assim que ela compara o movimento estudantil dos anos 70 com os atuais, o feminismo que se forjou naquele momento com os dias de hoje, e, ainda, as mudanças no sindicalismo e movimentos sociais. Provocando novas perguntas a quem interroga, recorre frequentemente a uma espécie de método comparativo, entre o momento atual e aquele que marcou os anos 60 e 70, que viveu em sua própria pele. Articula aspectos da "grande política com aspectos prosaicos do dia a dia, as amizades, as festas, as formas de organização e de resistência". Conta também como, rapidamente, naquele contexto, a indústria farmacêutica impôs-se no país, de forma a impedir o desenvolvimento de tecnologias "nacionais", algo absolutamente caro a ela, enquanto jovem farmacêutica e identificada com o marxismo, uma das suas referências mais caras e sempre evocado em suas falas públicas. 
Leitoras e leitores poderão perceber, ao longo de sua fala, os afetos entremeando as escolhas profissionais e políticas, em particular o casamento e a gestação e nascimento das filhas, assim como sua capacidade de estabelecer alianças com grupos de diferentes matizes ideológicos - os "caras" da alimentação natural, os comunistas, os vizinhos, os sanitaristas, os "gordos", como ela diz. Porém, sem nunca perder de vista sua formação inicial, orientada para o socialismo. De forma mais sutil, também se observa a importância das amigas ao longo de sua vida, a solidariedade entre mulheres que tanto valor tem para o feminismo. A referência aos grupos de mulheres de base, no qual esta sororidade se expressa nos grupos de "autoconhecimento" e no feminismo de base, não é casual: em suas palestras, Clair faz questão de referenciar a importância deste tipo de prática, sem jamais abrir mão da perspectiva mais ampla, da grande política, que é a mudança da sociedade capitalista.

Carmen Susana Tornquist (CST): Gostaríamos que você contasse, inicialmente, um pouco de sua trajetória de vida.

Clair Castilhos (CC): Eu nasci em Sant'Ana do Livramento, ${ }^{1}$ então eu sou uma mulher da fronteira do Rio Grande do Sul com o Uruguai. Nasci em 29 de outubro de 1945, imediatamente ao pós-guerra. Vivi em Santana do Livramento até ser jovem adulta. Estudei no Colégio Estadual Rivadavia Correa - onde fiz o primário inteiro. Minha mãe era professora lá também. Naquela época, os alunos dos colégios públicos eram muito bem reconhecidos, porque nestes havia um alto padrão pedagógico. Isto era na década de 50, no Período do Getúlio. Essa foi uma época em que a gente tinha uma formação muito nacionalista, de amor ao país, o que, comparando com os dias de hoje, eu estranho, porque eu ainda sou visceralmente nacionalista. Não tem papo comigo, esta coisa, de colonização! Nós tínhamos Semana da Pátria, era aquela loucura de preparação para os desfiles, arrumar o uniforme, limpar, ficar bem bonita, as gurias que tinham bicicleta iam à frente com as bicicletas enfeitadas de verde e amarelo e assim por diante. A gente cantava o hino nacional de manhã para hastear a bandeira e de tarde para arriar a bandeira, tudo isto no colégio. E também havia certas datas, a do Hino da Independência, a da Proclamação da República, entre outras. Uma vez por mês acontecia, na escola, no sábado de manhã, uma atividade que juntava todos os alunos e professoras para selecionar as melhores redações, que eram lidas para todos. Uma professora era encarregada de fazer o que chamavam de preleção, onde era lido um texto que a professora $X$ escrevia, explicando o assunto daquela data. Eu lembro que uma vez teve um tema que era: "Por que me ufano de ser brasileira?". Era o nome da redação. Minha redação foi premiada, eu tive que ler lá na frente. Eu achei bárbaro porque, mesmo sendo de Sant'Ana do Livramento, escolhi falar de todas as belezas do Brasil, desde o Pampa até a Amazônia. Naquela época, tinha a Cachoeira de Paulo Afonso e a Sete Quedas ainda não tinha se transformado em Itaipu. Falei disto, e também das tradições nordestinas, as nossas guerras, os Farrapos - enfim, foi uma "beleza" de tanto ufanismo. Esse foi um evento significativo na minha trajetória. Depois, então, eu entrei no ginásio. Como o ginásio estadual ficava bem longe do centro da cidade, todas as moças e meninas iam para o colégio das freiras, que era da Companhia de Santa Teresa de Jesus - uma ordem espanhola. Suponho, quando penso nisto, hoje, que devia ter alguma origem no Governo do Franco, na Espanha da época. Santa Tereza de Jesus era doutora da igreja, e considerada como uma santa superculta. Então, nossa educação religiosa não foi muito significativa, a não ser no mês de maio, que era o mês de Maria, aí a gente tinha que diariamente entrar quinze minutos antes na escola para rezar para a Nossa Senhora, na capela. Enfim, tive essa formação religiosa, mas tinha também a influência da história familiar. A minha mãe é filha de italianos (pai e mãe), mas ela e os irmãos nasceram todos aqui - o curioso é que, apesar dos pais italianos, eles não tinham nada de católicos. Meus tios, por exemplo, além de serem metidos a poetas, participavam do Parnasus Santanense, e eram anarco-comunistas. Minha mãe também teve uma trajetória um pouco diferente das outras moças da época: ela também fez o Norma/2 no colégio das freiras. Minha avó já era viúva, nesta época... eles tiveram um armazém muito forte, lá na fronteira, mas estes meus tios comunistas eram péssimos para negócios, dizem, e, obviamente, o armazém faliu. Então, além de eles fazerem poesia, ainda faziam marchinha dos Blocos de Samba da cidade (acho que não havia escolas de samba, mas blocos). Minha mãe, logo que se formou, precisou trabalhar, aí ela foi ser professora no Cerros Verdes, no interior do município de Sant'Ana do Livramento. Ela ia de carroça, e morava na casa de um dos alunos, cuja família oferecia a residência para alguém poder dar aula lá. Então ela teve essa experiência, sobre a qual, depois, ela nos contava muito. Não era a trajetória comum da mulher da época, que ficava

\footnotetext{
' Sant'Ana do Livramento (nome oficial da cidade) é chamada por alguns de Santana e, por outros, de Livramento. A entrevistada utiliza as três formas de se referir à cidade nesta entrevista.

${ }^{2}$ A entrevistada se refere ao curso do Ensino secundário, destinado a formar professores (em geral, professoras mulheres) para atuar no ensino primário, oferecido pelas escolas Normais e Institutos de Educação, que existiu no Brasil entre os anos de 1930 até 1971. Entre 1971 e 1996, corresponderam aos cursos de Magistério. Atualmente, este nível de formação profissional é oferecido no Ensino superior, correspondendo aos cursos de Pedagogia.
} 
em casa, casava, se formava, mas já expressava um período de transição também - década de 1945. Quando minha mãe era professora ainda eram os anos 40 e poucos. Minha mãe foi para Sant'Ana e ficou trabalhando em num colégio na cidade, mas antes ela conheceu meu pai, que era da Polícia Civil. Meu pai era o típico representante da burguesia rural decadente do Rio Grande do Sul. Meu bisavô era o Juca Tigre, famoso na região, nas revoluções de época. Era primo-irmão do Júlio de Castilhos, mas eles eram inimigos políticos, porque meu avô era Maragato e o Júlio de Castilhos era Republicano, positivista. Meu bisavô era dono de terras, entrava numas brigas e acabou perdendo todas as estâncias, gado, tudo, na revolução, financiando as tropas. Meu avô também participou das revoluções da época e o meu pai também. ${ }^{3}$ Meu pai lutou tanto para tirar o Getúlio do governo como antes lutara para botar o Getúlio no poder! ${ }^{4}$ Que ironia, né? Foi nesta época que meu pai veio para Santa Catarina: um tio dele foi interventor em Santa Catarina no período do Getúlio, chamava-se Ptolomeu Assis Brasil. Jovem ainda, participou da revolução e chegou a morar no porão do Palácio Cruz e Souza, em

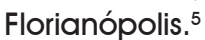

Olha o que é um mandato, não é? O tio dele, esse interventor, queria que ele entrasse no exército, mas ele não quis, então acabou entrando na Polícia Civil, e nessa condição é que ele foi transferido, já no Rio Grande do Sul, para Sant'Ana do Livramento, onde conheceu minha mãe. Ele trabalhava na repressão ao contrabando. Isto era muito comum na zona de fronteira, tinha muito roubo de gado e muito contrabandista de tudo que é lado. Ele chegou a ser comissário da polícia, e como minha mãe era professora, havia diferenças grandes entre eles. Mas quando havia os conflitos com os comunistas na cidade, ele era obrigado a participar das repressões, ia controlar os comícios comunistas, nos quais os meus tios estavam. Nunca esqueço o que a minha mãe dizia em casa: se tu prenderes algum irmão meu, eu me desquito!. E o pobre ficava naquela dualidade!

\section{CST: Ou perde o emprego ou perde a mulher!}

CC: ...perdia a mulher! Mas eu nunca o vi prender ninguém... Isto era interessante, lá em Sant'Ana: os comunistas iam para o exílio, ou seja, atravessavam a fronteira, isto é, atravessam uma rua, e iam para Rivera! ${ }^{6} \mathrm{E}$ aí, às vezes, a mãe chegava: ô Clair, te arruma porque nós vamos lá visitar o Ponfiglio que está no exílio. Ponfiglio era o irmão dela, a gente ia visitar o Ponfiglio no exílio. A família do Ponfiglio não foi para o exílio, ficou morando lá em casa com a minha mãe, a mulher dele, os filhos, todos, ficaram na casa do cara da polícia, então era uma coisa absolutamente contraditória; ou melhor, acho que era muito diversificada, porque a minha avó, a mãe do meu pai, era extremamente religiosa, morava em Bagé. Quando ela ia nos visitar era eu que ia com ela para a missa, que a mãe não ia muito à missa, era mais ou menos católica, mas não era assim aquela coisa, tanto que o meu pai era até mais religioso do que ela, ia mais vezes à missa e tal do que a mãe. Na verdade, ninguém era muito de [ir à] missa.

Enfim, essa minha vivência por Sant'Ana, até um pedaço da juventude, foi muito diversificada e com influências muito diferentes. Eu estudava no Colégio das Freiras, mas era um colégio muito peculiar, elas traziam pessoas de Porto Alegre para ministrar umas oficinas, poetas, artistas, uns caras até bem conhecidos, por exemplo, Bruno Kiefer, que era compositor e tocava violão, um outro chamado Delmar Mancuso, que era intelectual. Foi assim que, quando eu tinha uns 15 anos, entrei em contato com o Vinicius, com o Drummond de Andrade, tivemos um curso de teatro no qual nos ensinaram tudo sobre o teatro grego, história do teatro e tal, e eu me interessei por isso. Foi neste contexto de ginásio, aos 15, 16 anos, que eu resolvi virar existencialista.

Tem a ver com viver naquela fronteira de uma cidade importante do Uruguai. E perto dali tinha o famoso festival de cinema de Punta del Este - e praticamente todos os filmes da Nouvelle Vague que passavam no festival eram exibidos nos cinemas de Rivera! E aí, eu e minhas amigas, umas pirralhas, com 15 ou 16 anos, íamos ao cinema. Aliás, bem maquiadas, arrumadas, para passarmos por moças de 18 anos, porque senão não entraríamos no cinema. Foi nesta ocasião que eu assisti àquelas trilogias do Antonioni: A noite, O Eclipse, $A$ Aventura... depois vi os filmes do Fellini, de Godard - tudo nessa época, em Rivera.

\section{Silvana Maria Pereira (SMP): E eram filmes legendados ou não?}

\footnotetext{
${ }^{3}$ Referência à Revolução Federalista, que ocorreu no Rio Grande do Sul entre 1893 e 1895, dividindo a província em dois grupos: maragatos (contrários à centralização e às medidas do governo republicano inaugurado em 1889) e republicanos (ou chimangos), favoráveis à república recém decretada por Floriano Peixoto.

${ }^{4}$ Referência à Revolução de 1930, que viabilizou a chegada do gaúcho Getúlio Vargas ao Poder Central, representando novos setores da classe dominante, após décadas de domínio das oligarquias da região sudeste. A referência inclui o período da ditadura de Getúlio Vargas - Estado Novo - entre os anos de 1937-1945.

${ }^{5}$ O Palácio Cruz e Souza foi a sede do governo estadual catarinense até 1984, quando foi tombado e transformado em Museu.

' Santana do Livramento está situada exatamente sobre a linha de fronteira do Brasil com a República do Uruguai, ao lado da cidade de Rivera. As duas cidades são separadas apenas por uma avenida, constituindo uma área conurbada na qual as culturas de ambos os países se mesclam.
} 
CC: Todos com legenda em espanhol-entendia-se bem espanhol. A gente fala e lê perfeitamente o espanhol de fronteira. A gente também adquiriu muitos dos hábitos dos uruguaios, que era muito de ter vida noturna, de bar, de restaurante, de cinema. Então a gente ia para o cinema e, na saída, ia para os barzinhos, tomar um café, um cortado, umas coisas assim. Não se bebia muito porque éramos umas pirralhas, não é, mas tinha aquela coisa de chegar em casa meia noite, uma hora. Era bem diferente das minhas amigas de Porto Alegre: quando eu fiz o vestibular e fui para Porto Alegre, eis que as minhas amigas da capital eram muito mais atrasadas do que eu nessa questão mais ampla, de vivências culturais.

Como eu me interessei muito por teatro e gostava de cinema, tive uma experiência interessante: teve um menino, filho de mãe uruguaia e pai brasileiro, um ex-prefeito de Santana, que foi para Montevidéu e voltou de lá meio comunista. Ele montou um grupo de teatro no Partido Comunista do Uruguai, que era legalizado, e eu participei um pouco. A gente começou a montar Os Fuzis da Senhora Carrar, do Brecht, eu tinha uns 16 ou 17 anos. Afora isso eu jogava basquete, era do time de basquete do Colégio das Freiras, jogava vôlei, participava de tudo que era festinha também, não era do tipo esquerda cinza, nem sei se era esquerda também. Eu era bem refestelada; em tudo quanto era novidade eu participava. Teve um outro cara lá em Sant'Ana que saiu do seminário, metido a intelectual, e resolveu montar o Clube dos Vinte e Cinco, e me convidaram para ir, era um clube só de pessoas para leitura e discussão de livros. Teve uma época em que eu resolvi ser cronista, aí eu escrevi umas coisas medonhas, assim de adolescente, adolescente não, já era tudo neste tempo entre 15 a 18 anos. Eu e mais duas amigas, que éramos escritoras... Enturmamos com uma mulher que era cronista do jornal da cidade "A Plateia", ela era um tanto malfalada pelas más-línguas da província, mas esta mulher escrevia superbem. E a gente vivia quase sempre na casa dela, levando crônicas nossas para ela ler e avaliar. Bom, mas aí não vingou muito a minha história de escritora porque eu queria fazer faculdade, queria fazer medicina. Eu tirava nota boa, era boa aluna, mas não era muito estudiosa, dessas de ficar em casa afundada em livros escolares. Eu lia de tudo, eu colecionava Gibi, Pato Donald, Sartre, Françoise Sagan, tudo estava no meu repertório, além dos livros de sacanagem que a gurizada lia nessa idade, não é?

CST: E como é que tu acessavas os livros de sacanagem?

CC: Bah! A gente se passava na aula uma para outra..

CST: Até mesmo as meninas?

CC: Claro! Os livros eram envoltos noutra capa, que não era a verdadeira... Isto era normal, em pleno Colégio das Freiras... Minha mãe, muito prática, professora do primário, me disse um dia: então tá, tu queres fazer medicina, tu quer ir para Porto Alegre fazer faculdade, tu vais, mas tu tens que ter uma profissão, então tu vais fazer o Normal. Foi aí que eu fiz Normal de manhã e Científico de tarde, no Colégio Estadual. Por conta de participar de várias atividades, nós montamos a primeira chapa de oposição da União de Santanenses de Estudantes Secundaristas, e ganhamos a eleição, e eu fui eleita, não presidenta, mas do grupo da diretoria. Foi então que eu iniciei a minha vida política, em 1962, por aí. Foi quando eu fiz o meu primeiro discurso no rádio, quando a gente ganhou, na Rádio Cultura de Livramento, que a gente dizia GYG5, sei lá, 8 mega-hertz de Sant'Ana para o mundo (quer dizer, para Rivera! rsrs). Nós fizemos a passeata da vitória da oposição, a gurizada toda caminhando pela rua principal, e o meu pai na porta da delegacia, assistindo. E ele ficava até bem faceiro, sabe, não demonstrava muito, mas eu vi que ele gostava, porque a família dele era tudo metido nisso, nessas histórias de política.

Bom, aí eu acabei indo para Porto Alegre, e claro que fui encaminhada para o pensionato do Colégio das Freiras. Lá em Sant'Ana tinha o Colégio das Freiras, da Ordem de Santa Teresa de Jesus, que era da mesma congregação que o pensionato de Porto Alegre. Elas eram teresianas. Então, a maioria das gurias da minha geração que era do colégio das freiras e que foi fazer faculdade em Porto Alegre morava no pensionato. Só que durou dois anos, e as freiras nos expulsaram do pensionato, de tão insubordinadas que a gente era. Por exemplo, como as freiras abriam o pensionato às seis da manhã para a missa, essa era a hora que a gente chegava dos bailes e das festas! Festas do Centro Acadêmico, Baile da Reitoria, aquela coisa toda. Boates tinham muitas em Porto Alegre: tinha o Encouraçado Butiquim, ${ }^{7}$ a gente vivia enfiada no Encouraçado. Mas também era de grupo clandestino de esquerda no Centro Acadêmico da minha faculdade, mas, nesse momento, eu já estava definida [politicamente]. Nos primeiros seis meses eu fui morar na casa de uma prima-irmã minha que tinha sido criada com a minha mãe, elas tinham quase a mesma idade. Ela era casada com um cara que era promotor e era comunista. Eles viveram o tempo do golpe, 64 para 65, ele ficava alucinado lendo as notícias e tal, superirritado e furioso com as coisas, e eu antenadíssima e captando tudo... ah, não deu outra!

\footnotetext{
${ }^{7}$ Bar porto-alegrense, cujo nome fazia referência direta ao filme homônimo do cineasta russo, Sergei Eisenstein, Encouraçado Potenkin.
} 
Logo depois eu entrei na Faculdade de Farmácia em Porto Alegre, e não na Medicina, mas eu estava inscrita para fazer o vestibular de Medicina em Pelotas. Ali eu fui com meu primo, a Pelotas, para fazer o vestibular. Mas quando eu olhei Pelotas, vi aquela cidade e tal, falei não, eu vou ser farmacêutica em Porto Alegre, eu não vou morar aqui! Voltei para Porto Alegre, entrei na faculdade na boa. Em seguida, fizemos turma, e durante os meus quatro anos de faculdade, fui a representante de turma no Conselho de Representantes do Centro Acadêmico, disputei a eleição do Centro Acadêmico, fiquei uma vez de Secretária de Assistência Social da chapa do diretório que ganhou. Esta era a turma que organizava também as passeatas contra a ditadura, contra a Guerra do Vietnã, e a gente tinha todo um esquema de sair para rua e uma cuidando da outra. Estava acertado que não podia ter nada escrito, papel nenhum, porque se a gente "caísse", a gente não ia dizer (delatar os outros), então tu sabia de cor quem estava, organizava os grupos em cinco, seis e uma era a responsável por aquele grupo, dos cinco ou seis que estavam ali, de cor, mas sabia... e tinha os pontos (endereços) para se encontrar depois das passeatas. Fizemos de tudo, tomamos de assalto a Reitoria e o curso de Filosofia da UFRGS, depois a Sociologia e Direito, que estavam todos aliados no mesmo processo do diretório central dos estudantes, DCE. O golpe tinha acabado com as UEES e virou Diretório, não tinha mais centro acadêmico, e eu participava disso tudo. Ficamos lá nas passeatas, nas vigílias cívicas da frente da universidade, a polícia de choque cercando tudo, aquelas coisas... Como a gente era da farmácia, a gente era encarregada de garantir a segurança química da ocupação, ou seja, a gente roubava os produtos químicos do laboratório, bicarbonato, essas coisas, fazia as soluções para molhar os lenços para anular os efeitos do gás lacrimogêneo, assim, o gás lacrimogêneo não fazia muito efeito. Então a gente tinha essa função, na qualidade de farmacêuticos.

Eram todos cursos de esquerda, total. Foi por isso que a gente tomou estas faculdades, o Direito também, tinha uns guris de esquerda. Nessa época, aconteceu o famoso Congresso de lbiúna, ${ }^{8}$ eu concorri, mas perdi por um voto, e aí não fui. A gente fazia eleição escondida, tu não podias botar urna para indicar os teus candidatos para lbiúna, então, fazíamos eleição nos bolsos dos aventais (a gente usava avental pro laboratório) então, passávamos nas salas de aula, como quem não quer nada, e o pessoal ia colocando as cedulazinhas dentro dos bolsos. Depois, a gente contava e via quem eram os eleitos. Quando eu terminei a faculdade, obviamente, já estava num partido clandestino. Lembro que os três primeiros livros que me deram para ler foram: A Origem da Família, da Propriedade Privada e o Estado [de Friedrich Engels (2011)], A história da riqueza do homem [de Leo Huberman (1980)] e um outro livro sobre o feudalismo. Estes eram os três com os quais a gente se iniciava nesse grustapo que estudava o Partido Comunista. E nas passeatas e comícios do movimento estudantil não tinha assim, tudo disfarçado, como passou a ser mais recentemente, com relação aos partidos e às tendências, isto era muito claro, o pessoal dizia: agora vai discursar aqui o pessoal da IV - a IV Internacional, ou seja, os trotskistas, agora o PCbão` não tinha papo! Não era nomezinho de fantasia, sabíamos quem estava falando, sabe, os nossos discursos eram muito claros, e falávamos de derrubada do poder, fim da ditadura e de mudar o modo de produção no país.

Ao contrário do que eu observei mais tarde, quando já era professora, na UFSC: o pessoal do PCdoB, por exemplo, se identificava como Viração, e o pessoal do PCB se chamava de Unidade na Luta, algo assim. Então, isto era diferente, naquela época, a relação com os partidos era explícita. Vejo que mudaram as características das lutas também, mais adiante, não era mais "derrubar, tomar o poder", nada disso, e se passou a falar em luta pelo preço do RU, pelas passagens de ônibus - a meu ver, parecia uma coisa mais administrativa, os encaminhamentos das lutas, mas, enfim, entendo que isso depende da tática que tu vais adotar para trazer mais gente para os movimentos, de acordo com cada momento da História.

SMP: Voltando um pouco em um ponto que nos pareceu muito interessante: como foi esta tua ida para São Paulo, ainda no tempo da ditadura?

CC: Eu estava ferrada com a situação lá no Rio Grande do Sul. Meu pai recebeu um amigo dele que disse: Se tua filha quiser arranjar algum emprego, manda ela embora daqui porque ela tá queimada no DOPS. Então, meu pai disse: Bom, então vai para São Paulo. E fui para São Paulo, que virou outro evento em termos da diversidade das minhas vivências.

Fui morar no [bairro] Bom Retiro, na casa de uma família de judeus amigos nossos desde sempre, quando eu morava em Sant'Ana, que haviam se mudado para São Paulo. Eram os mesmos que moravam em frente da nossa casa, era um casal e dois filhos; ela fugiu de um campo de concentração da Polônia com 14 anos, a senhora, e veio para a Bolívia, acabou casando porque a comunidade se ajudava. Ela casou com um homem até bem mais velho que ela, na Bolívia, e foram para Sant'Ana, para área de fronteira. Eles tinham dois filhos, o Isaac e a

${ }^{8}$ Referência ao $30^{\circ}$ Congresso da União Nacional dos Estudantes (UNE) que aconteceu em outubro de 1968, clandestinamente, no interior de São Paulo. O congresso foi reprimido pelo Governo Militar, decorrendo desta ação centenas de prisões.

${ }^{9}$ Forma com a qual o PCB é referido, para diferenciá-lo do PCdoB, criado na década de 1970. 
Laia. E ela ficou amiga íntima da minha mãe, iam as duas de braço dado para Rivera, para o cinema, e minha irmã era amiga da filha e eu do guri. A gente jogava xadrez com o tabuleiro do pai dele, que nos emprestava, aprendemos juntos, eu e ele. O Isaac estudava no Colégio dos Padres, colégio religioso, e eu fui madrinha de formatura do Isaac, e ensinei ele a dançar - era aquela coisa toda assim. Mas a minha melhor amiga da vizinhança, com quem eu vivia grudada também, era da família Ludwig, que tinha casas de comércio tanto em Sant'Ana como em Rivera. Eram descendentes de família de alemães que vieram também para o Brasil, muito antes do período da guerra. Eles não tinham muito a ver, mas, sabe como é, não é? Então, tinha todo o "eixo" na minha rua, as outras amigas íntimas da minha irmã eram filhas dos donos de um hotel que era de uma família de italianos que tinha mudado para Sant'Ana. Então era aquela zoeira, como ocorre nas cidades de fronteira em geral. Muito, muito interessante. E a gente se dava com todos, éramos vizinhos e superamigos!

Quando fui para São Paulo, não conhecia ninguém, então a minha mãe sugeriu que eu falasse com a Dona Eugênia. Assim que fui morar na casa dela, fiquei morando no bairro judeu, participando das festas hebraicas com o Isaac, ficava lá com eles. Mas era para eu arranjar emprego. Tinha um professor meu de Físico-Química ou Rádio-Química da universidade, que me deu uma carta de recomendação para eu trabalhar num laboratório em São Paulo, o Laboratório LAFI. Este laboratório tinha acabado de ser vendido para os americanos da United States Vitamin. Bom, eu fui porque o professor que me recomendou era conselheiro do Conselho Federal de Farmácia, e o presidente do Conselho era o farmacêutico responsável desse laboratório. Aí eu fui, e ele me admitiu como estagiária. Comecei fazendo controle de qualidade de medicamentos, pesando comprimidos. Encontrei uma outra farmacêutica, formada em Araraquara. Fiquei amiga dela e nós começamos a ficar indignadas porque o chefe dos farmacêuticos era prático de farmácia. E aí nós começamos a "envenenar" os outros farmacêuticos: olha só o desaforo! Um prático de farmácia chefiar os farmacêuticos! No laboratório cujo farmacêutico responsável é o presidente do Conselho Federal, isso não dá para admitir! Resultado: não durei três meses no estágio, o cara me botou para rua, mas não queria se queimar com o colega dele de Porto Alegre, eu acho, e me encaminhou para o INPS que, na época, estava fazendo seleção de farmacêuticos, enfermeiros, médicos, tudo. É que abriu o Hospital Heliópolis, que era do antigo IAPI, ${ }^{10}$ eu fui ser entrevistada pela farmacêutica, chefe da diretoria de assistência farmacêutica da Previdência Social de São Paulo, da coordenadoria de São Paulo. Ela me entrevistou, gostou, e me contratou. Muito objetiva, era bem tempo de ditadura: tu é a favor do governo? Como é que tu é? Aí eu não disse nada: não, dentro do meu serviço como farmacêutica eu não posso ser a favor nem contra nada, eu tenho que ser farmacêutica. Aí ela sacou qual que era a minha, mas disse que gostou das minhas respostas, que era tal e me levou para lá. Em seguida, a Mareli, que era essa minha amiga, também foi demitida do LAFI. Ela também foi entrevistada no INPS. A chefe gostou dela, e, assim, fomos as duas para Heliópolis. O hospital era bárbaro, recém-inaugurado, então passava o dia inteiro enfiada na farmácia, alucinada por aqueles medicamentos todos, enturmadíssima com o pessoal da enfermagem porque era também um pessoal novo, implementando o hospital, mas tinha umas enfermeiras velhas, daquelas antigas que sabiam tudo, que davam as tintas lá dentro. A partir da chefe do hospital, que era a Dona Ondina, enfermeira antiquíssima, e o diretor do hospital, que era o Dr. Sebastião, que era médico, mas comia na mão da Ondina, porque era mais jovem, e a gente, em seguida, fez, digamos, altas relações dentro do hospital. E vida de hospital, sei lá, eu acho maravilhoso, porque tu tens muita vivência multiprofissional, não é? Tem a equipe hospitalar, aquela coisa toda, e eu era fanática, estudando remédio, para cima e para baixo, e ainda com a Mareli... Um dia, uma das chefes de enfermagem chegou para mim, bem quando estava faltando um determinado medicamento, e disse: olha, tu abre o olho, porque paciente internado não levanta do leito para ir comprar remédio lá fora, é tu que tens que garantir! E isso quando eu tinha 23 anos. Daí, encaramos a farmácia. A tal farmácia virou modelo - no final, o diretor clínico, um médico, veio me convidar para fazer uma pesquisa conjunta sobre antibióticos. Nesse meio tempo, fui liberada para fazer o curso de Administração Hospitalar na Faculdade de Saúde Pública da USP. Quando fui me inscrever, vi que havia duas opções: Administração Hospitalar e Saúde Pública propriamente dita, os currículos dos cursos estavam fixados lado a lado. Li o currículo de Saúde Pública e vi que tinha Sociologia, Epidemiologia. Eu pensei: não vou mais me inscrever em administração, vou me inscrever no Curso de Saúde Pública. Me inscrevi, passei e fui aceita. Enquanto isso, o Alcides estava se formando em Medicina na UFSC e decidiu fazer Saúde Pública na USP. Este curso durava um ano, com 8 horas de aula por dia, e foi no final do curso que a gente se conheceu, bem no fim do ano. Aí, namoramos, mas logo ele veio para Santa Catarina e eu fiquei em São Paulo, porque voltei para Heliópolis. Porém, em julho de 1973, a gente se casou - agora fizemos 44 anos de casamento.

10 Instituto de Aposentadorias e Pensões dos Industriários, criado em 1936, no governo de Getúlio Vargas, e que em 1966 originou o INSS. 
CST: Mas vocês se viam com frequência, nesta época, vivendo em estados diferentes, e namorando?

CC: Íamos de um estado para outro de carro, de ônibus, uma zona! Mas o interessante é que eu ainda estava metida com os movimentos clandestinos na época, eu era do PCdoB - Ala vermelha, que era um grupo de guerrilha urbana, mas eu era muito merreca. Eu não estava assim no auge da coisa, eu estava ali, era uma celulazinha de três que tu nem sabia o nome verdadeiro um do outro. É que a gente marcava pontos de vez em quando para se encontrar, passar as instruções, as coisas que precisavam de atividades que poderiam ser feitas, documentos para estudar, coisas assim, e nessas vezes eu não encontrava $\circ$ Alcides, dizia que "tinha compromisso", mas que não podia dizer o que é que era, ele ficava muito "grilado", não entendia direito.

Até que meu grupo se dissolveu porque as pessoas tiveram que ir saindo, era o auge da Operação Bandeirante (OBAN), e as pessoas foram se dispersando - então eu fiquei sem um grupo na época, ficamos só nessa função. Então me formei, casamos, vim para Criciúma. Foi o Alcides que fundou e organizou o terceiro CARS em Criciúma, o Centro Administrativo Regional de Saúde, ele foi o primeiro coordenador de lá. Quando eu saí do curso de Saúde Pública eu ainda estava no hospital. Mas eu andava muito invocada para entender porque é que a profissão de farmacêutico era tão desmoralizada, tão sem credencial, sem muito crédito. Imagina, num hospital de Previdência Social, o auge era ser médico, e as enfermeiras, lógico, porque eram quem verdadeiramente tocavam o hospital. E nós, os farmacêuticos, a gente estava lá, enfim, para entender os remédios, entregar os medicamentos. Mas nós atingimos um patamar maior, a Mareli e eu, porque a gente estudava muito, conhecia bastante os medicamentos. Aí fiquei pensando mas por que que é essa esculhambação? Um dia, caiu nas minhas mãos o livro do Mário Vitor de Assis Pacheco (1979), que se chamava Máfia dos Remédios. Ele escancarava, no livro, todas as questões das multinacionais agindo sobre os medicamentos, envolvendo a destruição dos cursos de Farmácia. Falava do domínio da indústria sobre a saúde e tal. Eu fiquei enlouquecida na época, estava no curso de Saúde Pública, terminei de fazer o curso e eu ia terminar por ali. Mas aí o Alcides queria fazer o mestrado, porque o interesse dele já era a docência. O meu não era - eu nunca pensei em ser professora de universidade, mas aí ele falou: faz o mestrado, faz, o que é que custa, nós já fizemos especialização, tem muitas disciplinas que servem de crédito para o mestrado, faz! Aí ele nos inscreveu no mestrado e passamos os dois. A minha dissertação teve como título "Contribuição para uma Política Nacional de Medicamentos". E foi neste contexto em que eu entrei para o Movimento Sanitário, que se formava na época. Logo o Alcides foi transferido para Floripa. Foi indicado para fazer o curso de Planejamento em Saúde em São Paulo e eu fui para fazer disciplinas do mestrado. Aí eu já estava na licença de gestação da minha filha Letícia, logo depois, na licença de gestação da Isadora [filha], eu fiz a qualificação e defendi o trabalho durante a licença de gestação da Maíra [filha]. Minha linha de pesquisa foi essa, mas eu sempre fui muito ligada em História, adoro História, eu queria fazer o curso. Assim, para introduzir o tema, eu pesquisei a história do medicamento no mundo e no Brasil, desde a transformação, no Brasil, das boticas em laboratórios industriais farmacêuticos e dos herbários dos jesuítas, quando eles se juntaram com as ervas dos índios e fizeram as primeiras teríagas brasilica, que era um medicamento com mais de 500 fármacos que servia para tudo. Era uma cópia da teríaga francesa, que era um polifármaco, meio mágico, manipulado no centro de uma praça pública em Montpellier. Na presença do oficial do rei, aí era fracionado e os caras saíam com aqueles vidrinhos vendendo. Aqui no Brasil fizeram a teríaga brasilica na junção com as ervas medicinais dos indígenas. Foi no governo do Marquês de Pombal que vieram de Portugal ordens excluindo os jesuítas. Diz que a busca da teríaga brasilis - a fórmula - foi uma das coisas que eles mais procuraram, mas não acharam. Somente foi encontrada 100 anos depois, na Biblioteca do Vaticano. Então tinha histórias assim que eu lia na minha pesquisa e ficava fascinada. Bom, eu dei voltas e voltas e acabei discutindo a indústria farmacêutica, sua formação, a desnacionalização durante a ditadura militar, todo o processo, enfim, pois também analisei a Central de Medicamentos (CEME), sua criação e influência e, logo depois, a alteração de todos os currículos do curso de Farmácia. Isto foi orientado pelo Ministério da Educação, em 1967, com o Jarbas Passarinho. Ficou claro o mecanismo das multinacionais para desestruturar - conhecimento farmacêutico, e esta foi a tese central do meu trabalho, ou seja, constatei que fatores externos ao ensino e à profissão farmacêutica influíram na formação do farmacêutico. E consegui comprovar. A CEME foi criação do governo do Médici. E foi feita sabe por quê? Porque eles chegaram à conclusão de que, se o Brasil entrasse numa guerra com as potências, ou num desentendimento, nós teríamos estoques de medicamentos no Brasil para somente uma semana. E ele, então, na lógica do pensamento militar, pensou vamos começar a produzir aqui. E aí fizeram a Central de Medicamentos, que não durou muito, aliás. Foi quando a gente descobriu a primeira aspirina nacional, com síntese feita aqui, mas eles desestruturaram a CEME. Quem orientou o meu trabalho foi um professor de Administração Sanitária, o Tinoco, que era dentista, sanitarista, tridoutor, mas era muito progressista para época, orientou a mim e ao Alcides. No 
começo, a nossa orientação fora do Dr. Reinaldo Ramos, mas depois ele se aposentou, no meio, passou para o Tinoco, aí nós ficamos com o Tinoco. Daí fiz a minha pesquisa, para a qual usei os livros e teses daquele pessoal também, do Hézio Cordeiro, do [Sérgio] Arouca, do pessoal que estava na cabeça do movimento sanitário.

SMP: Movimento pela Reforma Sanitária!

CC: Foi por isso que eu me animei. Havia concurso para professor no Departamento de Saúde Pública. E aí, o Alcides: vamos fazer o concurso? Eu respondi: eu não vou fazer concurso nenhum, vou ser farmacêutica do INAMPS (na época do INPS ainda). Mas, enfim, no outro ano abriu novamente o concurso e acabei tirando o primeiro lugar. Aliás, fiz dois concursos, para Saúde Pública e para Ciências Farmacêuticas, tirei primeiro lugar nos dois, porque eu já tinha os conhecimentos de medicamentos do tempo da Farmácia, lá do Hospital Heliópolis, e a Saúde Pública porque minha tese já estava orientada para essa área.

SMP: E como que você entrou na vida política?

CC: Uma boa pergunta! É que nós estávamos dando aula, então, e o Alcides e eu tínhamos um discurso bastante diferenciado dos demais professores nas aulas de Saúde Pública. Nossas alunas eram umas do PCbão, outras eram prestistas, que tinham acabado de romper com 0 $\mathrm{PCB}^{11}$ e estavam organizando uma esquerda dentro do $\mathrm{MDB}$, isto mais ou menos em 80 , aí a gente entrou e começou a participar das lutas políticas no município. Nesse meio tempo, sai a eleição de 1982, o nosso grupo se reúne e diz: bom, nós temos que ter candidatos daqui. Indicaram o Alcides e eu, o Alcides disse que não queria concorrer. E eu aceitei na hora!

Então fui eu a candidata [à vereadora]. Começamos a organizar a campanha, e como eu não era afiliada a nenhuma das tendências, tive apoio, na época, dos prestistas que tinham acabado de romper com o PCbão, seguiam a carta do Prestes. Tinha as mulheres do PMDB e as feministas de então, as poucas. Tinha o PCdoB, o pessoal das comidas naturais, o povo de acupuntura, fitoterapia e homeopatia, os meus vizinhos do bairro, do bairro em que eu vivia, porque, claro, eu morava aqui, enfim... era um comitê muito amplo, tinha umas cem pessoas. E ficamos uns dois, três meses construindo uma carta de proposta eleitoral que dificilmente contemplaria a todos. No fim, chegamos a um consenso pelo menos da palavra de ordem, que era: Pela convocação de uma assembleia nacional constituinte precedida da queda do regime militar. Começamos assim, 'porrada'!

Um companheiro bolou um cartaz com o seguinte mote: A gorda contra o regime da fome! Com este mote, eu ganhava os dois lados, não é, as gordas que se assumiam de serem discriminadas e a esquerda, porque dizia, de forma inteligente, que essa palavra de ordem tinha duplo sentido, não é? E aí nos elegemos todos. Fiz o meu primeiro mandato sem ser completamente feminista, apesar de eu fechar com as mulheres - na minha proposta, tinha mulheres, mulheres negras, duplamente discriminadas por serem mulheres e por serem negras. Foi aquele discurso padrão, mulher discriminada e tal, mas não entrei ainda... não entrava, nem era muito na moda essa coisa dos LGBTs, isso aí nem se falava...

Mas da mulher negra sim, já se falava na discriminação - falamos muito na questão da dupla jornada do trabalho, do salário igual para trabalho igual. Mas ocorreram dois eventos marcantes quando eu já estava eleita. No início de março de 1983, eu fui convidada para uma reunião no Rio de Janeiro, um seminário cujo título era Meu corpo me pertence, organizado pelas mulheres que tinham vindo de vários lugares, ou de exílio ou que estavam no exterior, e organizaram vários grupos feministas pequenos assim - a Branca Moreira Alves, a Danda Prado, a Jacqueline Pitanguy, a Santinha, a Comba Marques Porto, a Maria José de Lima, que eram mulheres que pensavam o Movimento Feminista propriamente dito, e tinham livros, produção de livro, de filme. Tinha a Eunice Gutman, que era cineasta junto com a Danda Prado, que era uma das donas da Livraria Brasiliense, a Fanny Tabak, aquelas feministas pós-75, ligadas ao Ano [Internacional da Mulher] da ONU - e essas mulheres eram incriveis! Elas convidaram as vereadoras eleitas, qualquer tipo, vereadora, senadora, qualquer uma que tivesse mandato, não interessava 0 partido e, além das outras mulheres em geral que estavam lá, foi um evento de três dias no Copacabana Palace.

Ao voltar, montamos um grupo em Florianópolis, começamos a nos encontrar. Quando eu vi aquela mulherada, aqueles discursos, aqueles debates, conheci pela primeira vez as bruxas, as fogueiras, a questão do aborto, do parto, uma outra lá falando que era possível ter orgasmo no parto natural, eu fiquei fascinada. Pensei: é isso o que eu quero, eu sou completamente feminista. Voltei de lá enlouquecida, cheguei na Câmara e pedi uma sessão especial para comemorar - 8 de Março na Câmara Municipal que até então não tinha, nunca teve, só tinha acontecido uma vez uma comemoração do 8 de Março no início dos 80 . Assim, foi feita a sessão especial.

\footnotetext{
${ }^{11}$ Referência à ruptura sinalizada pela Carta aos comunistas, que Luís Carlos Prestes lança em 1980, ao voltar do exílio, justificando a sua saída do PCB, que marca a emergência decorrente da política associada, desde então, ao seu nome (prestismo).
} 
Então, na sessão especial, tem um espaço no horário de oradores. Eu queria uma sessão solene, mas isso eu não consegui, com banda na porta para a gente entrar tocando O Rancho do Amor à $l$ ha.$^{12} \mathrm{~A}$ sessão especial teria quarenta minutos de horário de oradores, divididos entre as duas bancadas, para falar sobre o tema. E aí os vereadores do meu partido me indicaram porque eu fui a propositora, obviamente, depois da bancada da situação, na qual o cara falou rapidinho aquele discurso óbvio de homens (a minha esposa é mulher, a minha mãe é mulher, eu gosto de mulheres, nossa senhora é mulher, eu respeito as mulheres...), eu fui falar. O título do discurso foi Mulheres em luta - silêncio e resistência, no qual eu contei toda a história das mulheres, desde a Grécia, passando pela Idade Média, pelas bruxas, pelo diabo a quatro, destacando vários fatos, e cheguei ao feminismo - baseada no livro O que é feminismo? da Branca Moreira Alves e Jacqueline Pitanguy (1981).

Falei do livro da June Hahner (1981) sobre história política das mulheres de 1935 há não sei quanto, e terminei com o poema do Geir Campos (1964), Décima cantiga de acordar mulher, uma poesia linda que termina assim: "entre o tédio e bocejos, alguém diz à mulher acorda, é a tua hora de dizer teu depoimento". Foi esteticamente uma coisa bonita. Quando terminei, percebi um enorme silêncio, e eu pensei: vão cair de pau, afinal, usei todas as nossas bandeiras, inclusive a dualidade das mulheres, a religião, Eva e Nossa Senhora, a santa e a puta, isso e aquilo, e tal e tal, porra, vou levar... Mas notei que não era um silêncio agressivo... logo se levantou o Rogério Queiroz, um vereador do meu partido, dizendo silêncio, eu vou fazer para mesa, vou fazer um requerimento por escrito, eu quero que esse discurso seja impresso em quatro mil cópias para distribuição para população daqui! E aí fiquei pasma, não é?! Eles desandaram a elogiar o discurso, dizendo que nunca esperavam um negócio daqueles, alguns ficaram parados, outros estavam até meio emocionados, como se nunca tivessem ouvido falar um negócio daqueles! Foi daí que eu cheguei à conclusão de que os homens também são machistas, cretinos, porque são ignorantes também!

CST: É só eles terem acesso a um pouquinho de conhecimento...

CC: ...que eles se chocam, ficam chocados primeiro! E assim entrou na rotina. No segundo 8 de Março, que foi no ano seguinte, fiz uma homenagem para a Pagu e Olga Benário, mencionei as mulheres que morreram na Guerrilha do Araguaia, falei das mulheres negras, foi bem interessante, e esse eu terminei com o poema da Cecília Meireles, Mulher no espelho... lindo também! Minha referência à história da Olga Benário foi inspirada no livro do Roberto Drummond (1985), no qual ele conta a história de mulheres presas em Ravensbrück, um campo de concentração nazista. Incluí na referência a carta que a personagem (supostamente inspirada na Olga) escreve para sua filha, na qual ela dizia que ia morrer, mas que o fato de a gente ter a verdade, conhecer isso e aquilo, não nos tornará tristes. "Nunca deixe de dançar, de cantar, de ser feliz" ela escreve. E notei que havia alguns vereadores com uns olhos cheios de lágrimas quando eu terminei de ler. Este ficou sendo outro discurso dos Anais - mas este não mandaram publicar. Mas aplaudiram, foi muito legal... Já no terceiro 8 de Março... deu confusão na Câmara, porque aí eu avancei: resolvemos fazer o Tribunal do Ventre Livre na câmara! E aí levamos as mulheres do movimento feminista. Fomos na universidade e conseguimos as togas de formatura e vestimos todas. Uma delas era juíza e as outras eram testemunhas de acusação. Falamos contra o sofrimento das mulheres, uma falou da saúde, outra da educação das mulheres, outra das meninas de rua, outra da violência e sobre as mulheres negras. Havia música, chamamos o Severo Cruz [ator] para cantar, fantasiado de Jesus Cristo. Ele se dirige à bancada do PDS e canta: "Pai, afasta de mim esse cálice, Pai!". Aí, fechou o pau: a sessão foi suspensa, desligaram os microfones. Uma das nossas mulheres declamou um poema e quebrou um cálice no chão. Desligaram tudo, enquanto que a mulherada que estava assistindo invade o plenário, cantando "Maria, Maria" [canção de Milton Nascimento].

No outro dia, o presidente da Câmara de Vereadores me chamou para me dar uma bronca geral - assim, tipo guri de colégio. Eu retruquei: Qual é a tua, cara? Te flagra, eu sou tão vereadora quanto tu! Eles baixaram a bola, mas senti aquela coisa intimidatória. Mulher fazendo travessura na câmara... Não, sem essa! Depois disso, eles não deixavam muito mais espaço para as questões de mulher, mas continuamos fazendo. Esse mandato durou seis anos, porque, no meio do período, os milicos resolveram prorrogar os mandatos para desencontrar da eleição para prefeito, já que era a primeira vez que teria eleição para prefeitos de capitais e de cidades de área de segurança nacional.

Depois, nós fundamos a Casa da Mulher Catarina, em 1989. Em 1991, a casa foi uma das cofundadoras da Rede [Feminista de Saúde]. Desde aí eu vim militando intensamente no movimento feminista. Em 1995, o PCdoB me convidou para eu me filiar ao partido... Assim eu me filiei no PCdoB porque eu queria um partido comunista, que fosse mais combativo que os

${ }^{12}$ Hino da cidade de Florianópolis, composto pelo compositor popular Zininho. 
demais; no final, já não é o bicho também, não é, mas como diriam os [companheiros] do PCbão: é o que temos, não o que queremos... E é o partido em que estou até hoje.

Fomos um dos primeiros grupos a pensar num núcleo de estudos de gênero da universidade, a gente já se reunia, timidamente, digamos, nos anos 80 . Eu não continuei, porque já estava na Casa da Mulher Catarina, mas o pessoal continuou e formou toda essa maravilha de conjuntos de entidades que têm aí e compõem o que hoje é o Instituto de Estudos de Gênero e Revista Estudos Feministas. Tudo foi muito legal, eu estava aí.

Lembro que tem umas coisas que precedem o que é o feminismo geral em Santa Catarina. Começa lá por 78, e foi o Primeiro Encontro Estadual da Mulher Catarinense em Itajaí. Em 1978, juntamos quase quinhentas mulheres, depois, foi feito o Segundo Encontro, em Chapecó, que reuniu outras tantas quinhentas e, neste, não deixaram falar de aborto, nem pensar. Foi um seminário onde as mulheres de comunidades eclesiais de base estavam fortes, havia a Igreja no meio, eram lutadoras... Tinham debates sobre mulheres, mas... até um certo ponto. Nessa ocasião é que a gente sentiu que não ia dar para caminhar junto com essas entidades gerais, em tudo, e aí resolvemos formar o grupo feminista Vivências, que foi precursor da Casa da Mulher Catarina...

SMP: E a tua participação na Conferência de Beijing?

CC: Fui representando a Rede Feminista de Saúde. Neste contexto, as várias entidades de mulheres resolveram fazer uma articulação de mulheres brasileiras rumo à Beijing 95 e eu era desse grupo, aqui em Santa Catarina, junto com outras. A gente fez encontros preparatórios nos diversos estados. Nós tivemos também aqui um preparatório para Beijing. Depois, nos articulamos enquanto mulheres brasileiras, e definimos as pautas e suas condições de ir para Beijing, o que não era fácil. Eu consegui apoio porque eu fui lá no $\mathrm{BESC},{ }^{13} \mathrm{com}$ a maior cara de pau, falar com o diretor, e o convenci de que Santa Catarina não poderia ficar fora de uma coisa como essa e tal e tal e tal. Ele me deu um dinheiro para a passagem, aí eu fui para Pequim. Pequim fundou a articulação de mulheres brasileiras, mas quando nós voltamos de lá, essa articulação rumo a Beijing se transformou na AMB, que existe até hoje, a Articulação de Mulheres Brasileiras.

$\mathrm{Na}$ verdade, eu retornei ao movimento sanitário depois de ter atuado dentro do movimento feminista - pelo feminismo, porque, pela Rede, eu fui indicada para o Conselho Nacional de Saúde. Neste conselho estava todo o povo do movimento sanitário da época - assim eu me rearticulei de novo. E consegui, também, voltar à luta no campo farmacêutico. Tinha a CPI dos Medicamentos no congresso, que era aquela barbaridade. Isso aconteceu entre 2000 e 2001. Era uma vergonha total a canalhice das políticas referentes aos medicamentos. Resolveram fazer uma CPI, aí o relatório vai para o Conselho verificar e aprovar. E tinha um lá, o Mozart Abreu, que era do movimento sanitário, famoso, cheio de empáfia, insuportável. Era daqueles intelectuais de esquerda tidos como uma das cabeças do movimento sanitário, histórico. Pegou o relatório para ler; eu não aceitei muito a leitura que ele fez, comecei a discordar do relatório. Então, ele começou a se irritar, quis botar em votação e outras coisas mais... O Jucélio Dummond, que era da CUT, que estava lá, me sugeriu usar o recurso de pedir vistas: Pede vistas, conselheiros podem pedir vistas. Eu era nova no conselho, mas questionei o processo, pedindo "vistas", o cara ficou indignado - mas teve que me conceder as "vistas". Peguei o processo, vim para Santa Catarina, reuni os guris do Sindicato dos Farmacêuticos que tinham sido meus alunos, analisamos o relatório da CPI, eu disse: Nós vamos discordar, porque, pelo relatório da $\mathrm{CPI}$, as coisas mais graves em relação às multinacionais e a questão dos medicamentos não foram levadas em conta. Analisamos ponto por ponto e fizemos um substitutivo ao relatório. Ao chegar novamente na reunião nacional, apresentei o relatório e comuniquei que tinha uma proposta substitutiva já que eu não concordava com eles. O conselheiro relator ficou pasmo, disse: Como!? O que é que a senhora pensa? Tentou argumentar que tinha sido presidente da CEME, que era a pessoa que mais entendia de medicamentos etc. Mas eu contra-argumentei que eu tinha sido a farmacêutica que participou do grupo de trabalho que escreveu o projeto CEME-INPS e que tinha ficado 45 dias no Rio, com a minha chefe, para escrever este projeto. Aí o cara ficou parado, não é? Então eu disse: Sou farmacêutica, sou feminista, mas tenho outras atividades como cidadã! Na hora da votação dos projetos entre o substitutivo e o dele, - meu ganhou por 19 a 4 ! O cara ficou enlouquecido, foi bárbaro - bom, eu fiquei de "estrela" do conselho! Comecei a reivindicar que deveríamos nos contrapor a essa barbaridade [que é a política] de medicamentos no Brasil, que tínhamos que fazer uma conferência nacional de medicamentos e de assistência farmacêutica. Fizemos, então, uma Conferência - que eu coordenei -, a Primeira Conferência Nacional de Medicamentos e Assistência Farmacêutica de 2003. Foi no primeiro ano do governo de Lula. Mas foi uma pauleira aquela conferência! Eu fiz um discurso na abertura que ficou empolgante, foi um monte de coisa. Quando eu terminei de falar, a plenária levantou, aplaudindo. Aplaudiram muito, vi farmacêuticos antigos chorando, aquela coisa assim, porque eu fiz uma coisa bem performática - primeiro porque abri a conferência,

${ }^{13}$ Banco do Estado de Santa Catarina - banco público que foi incorporado em 2009 pelo Banco do Brasil. 
não é, eu, a coordenadora de braço com o ministro, que conduziu o ministro até a mesa, aquela coisa toda - o presidente da OPAS - e colocamos ao fundo a música do Jorge Ben, Os alquimistas estão chegando.

SMP: Você costuma ressaltar a importância dos pequenos grupos e das rodas de conversa entre mulheres, e busca sempre recuperar esta metodologia em outros âmbitos. Poderia comentar sobre isto...

CC: A gente trabalhava com oficinas, nosso trabalho era coletivo, não tinha isso de chegar e só dar palestra, ligar o data-show e ficar nisso. Eram as tais das rodas de conversa em busca de semelhanças entre as mulheres para se identificarem entre si, contarem as suas diferentes experiências e, nessas experiências, chegarem a pontos comuns de discriminação, de sofrimentos ou de lutas. Então, o movimento feminista era de grupos pequenos e trabalhava com essa metodologia, a gente até chamava de "Pedagogia Feminista". Era toda na base do relato, de contar as suas coisas, enfim, de autoconhecimento, a famosa oficina dos espelhinhos para olhar o próprio útero e tinha aquelas gozações: Ai, que lindo, olha que bonitinho o útero cor-de-rosinha e tantatan... Agora, a gente está voltando. Tenho recebido os convites ou relatos de gente me contando das rodas de conversa, oficinas de troca de experiências. Acho que isso é muito bom porque acabou grande parte dos financiamentos que vinham para as redes, financiamentos até internacionais, grande parte deles, que, de certa forma, deixou o movimento feminista meio acomodado e/ou cumprindo a agenda exterior. A gente não seguia nossa agenda interna, a gente cumpria aquilo que recebia financiamento. A Casa da Mulher Catarina nunca abandonou suas propostas, nós sempre tivemos ações locais, casa a casa, rua a rua, em atos públicos como quando mataram uma moça em Palhoça e a mãe dela queria justiça e não conseguia. Uma companheira da Casa da Mulher foi lá, com cartaz e tudo, participou de um ato público e conseguiram condenar o cara. Hoje, a mãe da moça que foi assassinada é presidenta no Conselho Municipal dos Diretos da Mulher de São José, e era uma simples empregada doméstica, inculta e todo o resto. Nós, da Casa da Mulher Catarina, fizemos oficinas de qualificação sobre violência contra a mulher com 500 Agentes Comunitárias de Saúde de Florianópolis e com 400 de São José [município da área conturbada de Florianópolis]. Depois fizemos oficinas de capacitação para os conselheiros municipais de saúde sobre a saúde das mulheres. Então surgiram dúvidas: Embora estejamos sem grana nenhuma... se a gente se entrega para essas financiadoras, estamos roubados.

É uma barbaridade isso! Olha, para acabar com o movimento, foi um triz. A gente não tinha mais base nenhuma, perdemos a força, porque enquanto potencialmente transgressoras $e$ revolucionárias a nossa força era o movimento que tínhamos por trás de nós. Aliás, é o que aconteceu com os sindicatos, não é?

SMP: E o que seria esta agenda interna, deixada de lado em muitos grupos feministas?

CC: Primeiro, não podemos nunca perder de vista que havia cada vez mais necessidade de ampliar a participação das mulheres dentro da ótica do movimento feminista. Há movimento de mulher para tudo que é coisa, mas muito por questões pontuais, e não tanto de uma ótica feminista. E no nosso caso, eu acho que a gente precisava participar da agenda nacional nossa articulação - principalmente na questão dos movimentos da política aqui no Brasil, para conseguir avançar com mulheres feministas em Câmaras, Assembleias, na Câmara Federal. Aliás, hoje o exemplo está claro, está cheio de pastores lá, fazendo regredir todas as nossas conquistas, inclusive a luta, nossa também, de avançar pela descriminalização do aborto, a questão da humanização do parto, enfim, o atendimento à saúde da mulher como um todo, não apenas em lugares específicos que são referência. Em especial, para no lugar interno, no país inteiro até nos pequenos municípios, entidades desse tipo, ter a outra, a luta intensa contra a violência institucional que existe contra nós, mulheres. É quando tu vais, por exemplo, dar queixa numa delegacia, sais de lá culpada; quando tu vais ter um atendimento médico, és tratada com menosprezo; quando tu fazes um aborto, então, nem se fala, porque és julgada, em vez de ser atendida, e é obrigação [do serviço público], né? E assim por diante. Então nós tínhamos uma ampla agenda e outras coisas que talvez a gente nem saiba porque não consultou com as mulheres quais eram as suas verdadeiras necessidades e ficamos cumprindo as coisas de cima para baixo. Claro que a agenda da ONU, por exemplo, de acompanhamento do $\mathrm{CAE},{ }^{14}$ tem o maior interesse para nós, sem dúvida, que era a questão dos direitos reprodutivos, da questão do aborto, a plataforma de Beijing da mesma forma, que trata da equidade, da paz, disso e daquilo, mas é que isso ficava lá nos fóruns mais restritos. Mas uma outra coisa que eu acho que a gente chegou até um ponto e não avançou foram as questões do ecofeminismo. Chegou mesmo a ter discussões sobre isso, e a gente tinha que ter um discurso mais estruturado contra esse povo que diz ah, eu sou pró-life, pró-vida, mas eles são alinhados com todos os "pró-morte"

${ }^{14}$ Conselho de Assuntos Estratégicos da ONU. 
que se conhece, que é o pessoal, por exemplo, do agronegócio. O agronegócio é a coisa mais "pró-morte" que se pode conceber! Já que acaba com a natureza, empesta os aquíferos, mata os quilombolas, mata posseiro sem-terra, mata não sei quem mais, acaba na devastação das florestas, acaba com as águas, já que cada plantação dessas, monstruosa, monumental, consome um potencial de água inestimável e ainda contamina os lençóis freáticos do país com agrotóxicos... E isso é ser "pró-vida"? Esses é que estão casados com os evangélicos na câmara e nós não temos representatividade - a bancada feminina é mínima, tem um pingo de mulheres que se dizem feministas ou que fecham com a causa. Mulheres ótimas, valorosas! O problema é que tem um certo número [de mulheres] que não serve para nada, entendeu? Que está lá só para cumprir a agenda dos homens.

Então, numa situação dessas, se não vamos conseguir mulher, nós temos que ter tática para eleger um homem sensível que feche com a causa, sabe? Então, todas essas questões táticas e estratégicas são prioridades nossas, que a gente precisa discutir e traçar uma forma de enfrentamento, enfrentar esse golpe da ditadura do capital - que é isso que nós estamos sofrendo - sem perder de vista o espaço e o avanço do movimento feminista ou como o movimento feminista é capaz de avançar dentro de uma conjuntura como essa, quais são as nossas bandeiras, o que é que a gente precisa... Uma coisa que me parece que é central na discussão hoje.

\section{Referências}

ALVES, Branca Moreira; PITANGUY, Jacqueline. O que é feminismo? São Paulo: Editora Brasiliense, 1981. (Coleção Primeiros Passos)

CAMPOS, Geir. "Décima Cantiga de Acordar Mulher". In: CAMPOS, Geir. Cantigas de Acordar Mulher. Rio de Janeiro: Civilização Brasileira, 1964.

DRUMMOND, Roberto. Hitler manda lembranças. Rio de Janeiro: Editora Nova Fronteira, 1985.

ENGELS, Friedrich. A origem da família, da propriedade privada e do Estado. São Paulo: Boitempo, 2011.

HAHNER, June. A mulher brasileira: suas lutas sociais e políticas (1850-1937). São Paulo: Editora Brasiliense, 1981.

HUBERMAN, Leo. Historia da riqueza do homem. Rio de Janeiro: Editora Civilização Brasileira, 1980.

PACHECO, Mário Victor de Assis. A Máfia dos Remédios. Rio de Janeiro: Civilização Brasileira, 1979.

Carmen Susana Tornquist (carmentornquist@hotmail.com) é licenciada em História pela UFRGS, mestre em Sociologia e doutora em Antropologia pela UFSC. Pesquisadora de temas relacionados aos movimentos sociais e pensamento social latino-americano. Participante da Casa da América Latina SC e do ANDES - Sindicato Nacional.

Silvana Maria Pereira (sil.pereira@gmail.com) atuou como enfermeira do Hospital Universitário, de 1985 a 2018, na área da Saúde das Mulheres. Mestre em Sociologia Política (UFSC, 1996), Estudos Avançados em Direitos Humanos pela Universidad Pablo de Olavide, Espanha (2006) e doutora pelo Programa de Pós-Graduação Interdisciplinar em Ciências Humanas PPGICH-UFSC, área de concentração Estudos de Gênero (2014). Pesquisadora do LEGH-UFSC. 


\section{COMO CITAR ESTE ARTICO DE ACORDO COM AS NORMAS DA REVISTA}

TORNQUIST, Carmen Susana; PEREIRA, Silvana Maria; MARCELLINO, Binah Ire Vieira. "Por entre lutas, entusiasmo e prazer: entrevista com Clair Castilhos". Revista Estudos Feministas, Florianópolis, v. 29, n. 2, e67900, 2021.

\section{CONTRIBUIÇĀO DE AUTORIA}

Carmen Susana Tornquist - concepção, realização da entrevista, edição, redação da apresentação.

Silvana Maria Pereira - concepção, coleta de dados e análise de dados, elaboração do manuscrito, redação.

Binah Ire Vieira Marcellino - transcrição da entrevista.

\section{FINANCIAMENTO}

Não se aplica.

\section{CONSENTIMENTO DE USO DE IMAGEM}

Não se aplica.

\section{APROVAÇĀO DE COMITÊ DE ÉTICA EM PESQUISA}

Não se aplica.

\section{CONFLITO DE INTERESSES}

Não se aplica.

\section{LICENÇA DE USO}

Este artigo está licenciado sob a Licença Creative Commons CC-BY 4.0 International. Com essa licença você pode compartilhar, adaptar, criar para qualquer fim, desde que atribua a autoria da obra.

\section{HISTÓRICO}

Recebido em 03/10/2019

Aprovado em 04/03/2020

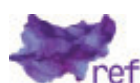

